\title{
Kahden sukupolven kattava perintöoikeus tekijänoikeuden keston perusteluna
}

\author{
Markus Rytinki \\ Oulun yliopisto \\ markus.rytinki@oulu.fi \\ https://orcid.org/0000-0003-0534-8930
}

This article addresses one of the most common justifications of the optimal duration of copyright in music business in Finland. The research material consists of half-structured theme interviews and the method used is theory-based content analysis. The interpretational theory used is the model of justification of copyright by Laura Leppämäki. Thirty-one informants representing a wide spectrum of expertise in Finnish music business were interviewed during MarchOctober 2016. The results state the following: Copyright is often seen as a natural item of ownership, claimed by work, and especially as a subject of inheritance, preferably for two subsequent generations. However, simple arithmetic discloses the current duration lasts longer than the average life expectancy of the grandchildren of the author. If two generations are seen as an optimal duration, copyright should last 60 years after authors death. The member states of EU have until June 7th 2021 to introduce the new Directive on Copyright in the Digital Single Market - in which the duration remains the current 70 years - within their countries. This article argues that if the duration is justified as a subject of inheritance, it should be shortened. Another possibility is to alter the justification entirely.

Asiasanat: tekijänoikeus, tekijänoikeusdirektiivi, perinnöt, lainsäädäntö, digitaalinen musiikki, immateriaalioikeus, luovat toimialat, musiikkiteollisuus

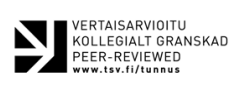




\section{Johdanto}

Euroopan unionin neuvosto hyväksyi 15. huhtikuuta 2019 uuden tekijänoikeusdirektiivin, jonka Euroopan parlamentti oli hyväksynyt aiemmin 26. maaliskuuta. Tämä tuore direktiivi, joka astui voimaan 17.5.2019 ja jonka koko nimi on "Euroopan parlamentin ja neuvoston direktiivi tekijänoikeudesta ja lähioikeuksista digitaalisilla sisämarkkinoilla”, sisältää nimensä mukaisesti useita muutoksia tekijän- ja lähioikeuksilla varustetun materiaalin levittämisestä ja käyttämisestä internetissä. Uusien sääntöjen on muun muassa tarkoitus parantaa sisällöntuottajien, kuten muusikkojen, mahdollisuuksia neuvotella paremmista korvauksista internetin alustapalveluiden kanssa. Direktiivin mukaan internetalustat, kuten YouTube, ovat suoraan vastuussa niihin ladatuista sisällöistä kuten musiikkikappaleista. Ennen direktiivin voimaantuloa teosten oikeuksien haltijoiden on pitänyt erikseen pyytää palvelua poistamaan ilman lupaa tarjolla ollut sisältö palvelusta ns. notice and take down -prosessissa. Tästä eteenpäin alustapalveluiden pitää hankkia lupa, jos ne haluavat välittää yleisölle käyttäjien lataamia, oikeuksia sisältäviä sisältöjä. Käytännössä luvat hankitaan lisensseinä tekijänoikeusjärjestöiltä kuten Teostolta. Uusi direktiivi tulee saattaa voimaan jäsenmaiden lainsäädännössä viimeistään 7. kesäkuuta 2021. (Euroopan parlamentti 2019) (Teosto 2019)

Suomessa julkiseen keskusteluun on noussut erityisesti direktiivin artiklat 15 ja 17 (ks. esim. Raivio 2019, Halminen 2019). Artikla 15 koskee sitä, kuinka pitkiä otteita lehtiartikkeleista saa esittää internetissä ilman lisensointia. Uudistuksen jälkeen yksittäisten sanojen tai hyvin lyhyiden otteiden käyttö on yhä sallittua, kuten myös hyperlinkittäminen. (Tekijänoikeusdirektiivi 2019/709, artikla 15) Artikla 17 koskee puolestaan juuri edellä mainittua alustapalveluita koskevaa uudistusta. Huolenaiheena on ollut, että esimerkiksi YouTube saattaa jopa lopettaa toimintansa Euroopassa kokonaan lainmuutoksen myötä. Direktiivin vaikutusten etukäteisarviointia on ylipäätään pidetty hankalana ja uudet käytännöt ja toimintamallit muotoutuvat vasta direktiivin tultua osaksi unioniin kuuluvien maiden lainsäädäntöä.

Tämän artikkelin tehtävänä ei kuitenkaan ole uuden tekijänoikeusdirektiivin tai siitä syntyneen keskustelun analysoiminen. Sen sijaan tavoitteenani on tuoda esiin väitöskirjani (Rytinki 2018) tutkimustuloksia, jotka koskevat tekijänoikeuden kestoa ja sen perusteluja, erityisesti Suomessa musiikkialalla suosittua nykyisen keston perustelua perinnön jättämisen mahdollisuutena. Viime keväänä hyväksytyssä tekijänoikeusdirektiivissä ei ole käsitelty lainkaan tätä tekijänoikeuskeskustelun pysyvää teemaa eli tekijänoikeuden kestoa, jolla on historiallisesti ollut taipumus pidentyä (ks. esim. Haarmann 2014, 49). Esimerkiksi Suomessa vuoden 1829 painoasetuksessa tekijänoikeuden kesto 
asetettiin 25 vuoteen tekijän kuolemasta. Tämä ei tietenkään ole yllättävää, sillä tekijänoikeuden keston uudelleenarviointi ei ole ollut agendalla uuden tekijänoikeusdirektiivin sisältöä laadittaessa. Tekijänoikeuden kesto onkin määritelty direktiivissä 2006/116/EY. Lähioikeuksien edellisessä direktiivissä määriteltyä suoja-aikaa puolestaan pidennettiin vuonna 2011 direktiivillä 2011/77/EU.

Koen, että tänä ja kahtena seuraavana vuonna käydyn ja käytävän tekijänoikeuskeskustelun pohjalta ja kannalta on hyödyllistä palauttaa mieleen, mitkä ovat nykyisen tekijänoikeuden keston suosituimmat perustelut. Tämä on tarpeellista siksi, että uuden tekijänoikeusdirektiivin 17 artiklan internetin alustapalveluille asettaman, lupien hankkimisesta seuraavan rasitteen määrä on suoraan yhteydessä siihen, kuinka pitkään tekijänoikeudet suojaavat teoksia. Perustelut puolestaan oikeuttavat keston ja toimivat sen teoreettisena perustana.

Tämän artikkelin tehtävänä on siis valottaa musiikkialan tekijänoikeuksien keston perusteluja, erityisesti suosituinta perustelua eli tekijänoikeutta työn kautta saatavana omistusoikeutena ja tämän omistusoikeuden kautta tarjoutuvaa mahdollisuutta oikeuksien jättämiseen perintönä tekijän jälkipolville. Tarkoituksena on kuvata, miten kotimaisen musiikkialan eri intressiryhmät perustelevat nykyistä tekijänoikeuden kestoa ja määrittää, onko yksi keskeinen perustelukeino - tekijänoikeus tekijän jälkeisen kahden sukupolven kattavana perintönä - nykytilanteessa validi vai ei.

\section{Tutkimuksen tausta}

Tämä artikkeli perustuu väitöskirjaani, joka käsitteli musiikkialan tekijänoikeuden kestoa, ansaintalogiikoita ja digitaalisen aineiston saatavuutta internetissä (Rytinki 2018, 7). Uudesta tekijänoikeusdirektiivistä keskusteltaessa kaikki kolme väitöskirjani tutkimusaihetta ovat edelleen relevantteja. Tekijänoikeuden kesto vaikuttaa alustapalvelujen tarvitsemien lupien määrään; alan ansaintalogiikat (tai ellei logiikat, niin ainakin alustapalveluista tuloutuvat tekijänoikeuskorvaukset ja niiden painoarvo musiikintekijöiden kokonaisansioissa) muuttuvat uudessa tilanteessa; (ilmaisen) digitaalisen aineiston saatavuus alustapalvelujen kautta voi vähentyä. Keskityn tässä artikkelissa ensimmäiseen osa-alueeseen eli tekijänoikeuden kestoon ja sen perusteluihin. Väitän, että se on tekijänoikeuden osa-alue, johon tekijänoikeuksista käytävä keskustelu tulee tulevaisuudessa aika ajoin palaamaan. Tästä syystä jokaisen keskustelusta kiinnostuneen tulee tuntea oikeuksien perustelut ainakin perustasolla. Olennaista asian käsittely on myös siksi, että tekijänoikeuksien 
kestoja sen perustelut muodostavat pohjan kaikelle muulle oikeuksiin liittyvälle toiminnalle. Kahteen muuhun väitöskirjani tutkimusaiheeseen, ansaintalogiikoihin ja digitaalisen aineiston saatavuuteen, palaan jatkotutkimuksissani myöhemmin uudelleen.

Tekijänoikeuden kestoon liittyvä tutkimuskysymys on muotoiltu väitöskirjassani seuraavasti (Rytinki 2018, 18):

Miten musiikin tekijänoikeuden kestoon suhtaudutaan ja miten optimaalista kestoa perustellaan suomalaisten musiikkialan toimijoiden keskuudessa?

Halusin selvittää, tulisiko tekijänoikeuden keston olla musiikkialan asiantuntijoiden mielestä nykyinen 70 vuotta tekijän kuolinvuodesta, sitä lyhyempi, vai sitä pidempi. Toiseksi halusin selvittää, miten tekijänoikeuden optimaalista kestoa perustellaan. Näihin kysymyksiin saamiini vastausten läpikäymisen jälkeen tuli tarpeelliseksi selvittää, minkälaisessa suhteessa tekijänoikeuden kesto on oikeuksien perijöiden keskimääräiseen elinikään. Näin jatkotutkimuksena voitiin esittää seuraava kysymys:

Miten tekijän jälkeisten kahden sukupolven keskimääräinen elinajanodote on suhteessa tekijänoikeuksien kestoon?

Tämän artikkelin tavoitteena on esittää vastaukset näihin kysymyksiin. Kuitenkin ennen tutkimusmenetelmien ja -aineiston esittelyä lyhyt kertaus tekijänoikeuksista on paikallaan.

Tekijänoikeus on voimassa 70 vuotta tekijän kuolinvuodesta ja lähioikeus 70 vuotta teoksen julkaisemisesta. Tekijänoikeus on osa immateriaalioikeuksia, jonka toisen puolen muodostavat teollisoikeudet kuten patentit. Tekijänoikeudet voidaan jakaa taloudellisiin ja moraalisiin oikeuksiin. Taloudellisten oikeuksien on tarkoitus suojella tekijän ansaintamahdollisuuksia. Tekijänoikeudet antavat tekijälle yksinoikeuden määrätä teoksen kappaleen valmistamisesta eli kopion tekemisestä sekä yleisön saataville saattamisesta (Haarmann 2014). Näin tekijä voi neuvotella teoksen käytön ehdoista ja saa palkkion siitä, että hänen luovaa työtään käytetään. Musiikkituottajien ja esiintyvien artistien asemaa turvataan lähioikeuksilla. Tekijänoikeuden kohteena on teos, kuten kirjallinen teos tai sävellysteos. Teoksen täytyy suojaa saadakseen ylittää teoskynnys eli teoksen täytyy olla itsenäinen ja omaperäinen. (Tekijänoikeuslaki 2015/607.) 


\section{Tutkimusmenetelmät ja -aineisto}

Käytin väitöskirjani tutkimusmenetelmänä aineistotriangulaatiota eli kyselytutkimusta, teemahaastatteluja ja kirjallisuuskatsausta. Tässä artikkelissa keskeiseen osaan nousee näistä keskimmäinen. Tutkimusmateriaali koostuu näin puolistrukturoiduista teemahaastatteluista, joissa musiikkialan eri intressiryhmät perustelivat näkemyksiään tekijänoikeuden optimaalisesta kestosta. Kyseiset eri intressiryhmien edustajat olivat hyvin artikuloivia ja pääosin keston optimia vivahteikkaasti analysoivia, edustamaansa yhdistystä tai yritystä edustavia henkilöitä, jotka olivat pääosin valmiita ottamaan huomioon myös oman näkemyksensä vastaiset perustelut ja käymään niiden kanssa dialogia. (Alan huippututkija Daniel Nordgård väittääkin, että suljettujen ovien takana monet intressiryhmät, kuten musiikkikustantajat ja levy-yhtiöt, olisivat valmiita tekijän- ja lähioikeuksien lyhentämiseen tai ainakin neuvottelemaan aiheesta vakavasti. (D. Nordgård, henkilökohtainen tiedonanto 14.12.2018.)) Näin haastatteluissakin syntyi, kuten tarkoituksena on, aitoa vuorovaikutusta pelkän kysymysten läpiluvun sijaan (Eskola \& Vastamäki 2010, 26).

Informanteiksi valikoitui monipuolinen otos musiikkialan eri toimijoita:

Taulukko 1. Informanttien edustamat intressiryhmät.

1) Musiikintekijät

2) Artistit

3) Levy-yhtiöt

4) Musiikkikustantajat

5) Tekijänoikeusjärjestöt

6) Musiikkialan yhdistykset

7) Managerit

8) Musiikkituottajat

9) Internet-palveluntarjoajat

10) Keikkajärjestäjät

11) Radiokanavat

12) Levykaupat

13) Musiikkikirjastot

14) Piraatit

15) Kuluttajat 
16) Palvelukäyttäjät

17) Asiantuntijat

18) Lainsäätäjät

19) Tutkijat

20) Suoratoistopalvelut

Valitsin tutkimuksen informantit väitöskirjani tutkimusalueiden ja aiempien musiikkialan tutkimusten perusteella. Pidin tärkeänä sitä, että tutkimukseen tuli mukaan myös tahoja, jotka liittyvät musiikin kuluttamiseen ja jakamiseen, mutta jotka eivät itse osallistu musiikkiteosten tekemiseen. Käsitykseni mukaan otos edustaa kattavasti musiikkialan ja musiikin kuluttamisen eri osapuolia. Nämä osapuolet ovat oman alansa huippuammattilaisia, jotka ovat lähtökohtaisesti ajatelleet musiikkialan kysymyksiä perusteellisesti. Perikuntien edustajia tutkimuksessa ei ole mukana, koska tietoa siitä, kuka oikeuksia nauttii, ei ole julkisesti saatavilla.

Haastattelin yhteensä 31 eri intressiryhmien edustajaa (27 kasvokkain toteutettua haastattelua ja 4 sähköpostihaastattelua). Litteroin tekstin itse selko- ja puhetyylin yhdistelmäksi, keskittyen viestin sisältöön. Toteutustapa oli näin ns. peruslitterointia. Valmista tekstiä tuli yhteensä 643 sivua, nauhoitusten keston ollessa noin 17 tuntia 45 minuuttia (yhden haastattelun mediaani 34 minuuttia 20 sekuntia). Haastattelut nauhoitettiin maalis-lokakuussa 2016 ja ne pohjautuivat aiemmin toteuttamaani kyselytutkimukseen. Haastatteluissa tekijänoikeuden kesto muodosti oman pääluokkansa musiikintekijöiden ansaintalogiikoiden ja digitaalisen musiikin saatavuuden ohella. Tekijänoikeuksien kestoon liittyviä mainintoja saatiin haastatteluissa yhteensä 288 kappaletta.

Analyysimenetelmänä käytin teorialähtöistä sisällönanalyysia. Sisällönanalyysin tavoitteena on saada tutkittavasta ilmiöstä yleistetty ja tiivis malli, jonka avulla voidaan luoda johtopäätöksiä (Tuomi \& Sarajärvi 2013, 108-111). Teorialähtöisessä analyysissa sisältö luokitellaan käytetyn teorian tarjoamaan viitekehykseen (Tuomi \& Sarajärvi 2002, 116). Tässä käytetty teoria/viitekehys oli Laura Leppämäen tekijänoikeuksien perusteluja koskeva malli, jonka hän esittää väitöskirjassaan "Tekijänoikeuden oikeuttaminen” (Leppämäki 2006). Leppämäen mukaan tekijänoikeuden perustelut voidaan jakaa neljään luokkaan eli 1) utilitarismiin, 2) työntekoon perustuvaan luonnolliseen omistusoikeuteen, 3) tekijän persoonan korostamiseen ja 4) demokratiavaatimuksiin.

Esitän seuraavaksi - hyvin lyhyesti - kohdan 2 eli työntekoon ja luonnolliseen omistusoikeuteen liittyvän tekijänoikeuden keston perustelun, koska se 
toimii tutkimuksen aiheena olevan perintöoikeuteen vetoamisen teoreettisena pohjana.

Teoksen, kuten musiikkikappaleen, valmistamiseen tarvitaan vaihteleva määrä työtä. Tämän työn tekeminen luo teokseen luonnollisen omistusoikeuden, jolloin tekijä voi hyötyä taloudellisesti luomastaan teoksesta. Tämä näkemys pohjaa Leppämäen (2007, 81-2) mukaan John Locken omistusoikeuden teoriaan. Se on samalla voimakkain ja yleisesti ottaen suosituin kaikista tekijänoikeuden oikeuttamisen perusteluista.

Locken (Leppämäki 2006, 22) liberalistisen näkemyksen mukaan työ kuuluu tekijälleen. Omistaminen syntyy silloin, kun omaa työtä sekoittaa hyödykkeiden tuotantoon. Omistaminen on palkinto siitä, että yksilö on jaksanut tehdä (usein) epämiellyttävää työtä. Tätä Locken fyysiseen todellisuuteen ja aineelliseen omaisuuteen liittynyttä teoriaa sovelletaan henkisen omaisuuden - tekijänoikeuksien ja myös digitaalisen musiikin kohdalla siten, että henkisestä omaisuudesta luodaan ensin rinnastus aineelliseen omaisuuteen, jonka jälkeen vedotaan Locken omistusoikeuden teoriaan. Näin vanhaa, materiaalisten objektien omistamista varten kehiteltyä teoriaa voidaan soveltaa myös henkisen ja digitaalisen omaisuuden omistamisen kohdalla.

Viimeisen kahden vuosikymmenen aikana tekijänoikeuskeskustelussa on noussut esiin myös tekijänoikeuden nykyiseen kestoon kriittisesti suhtautuvia näkökantoja. Niiden mukaan liian pitkä tekijänoikeus mm. uhkaa kansalaisyhteiskuntaa ja eristää ihmisiä. Kriitikkojen mukaan oikeuksia pohdittaessa tulisikin ottaa huomioon myös sivistykselliset ja sosiaaliset näkökulmat (Leppämäki 2007, 82.) Tärkein käytännön uudistus on Creative Commons -lisenssi, jonka avulla teoksen voi asettaa yleisön saataville siten, että automaattisesti syntyvistä tekijänoikeuksista luopuu osittain tai kokonaan. Malli perustuu kilpailun ja poissulkemisen sijaan jakamiselle ja yhteistyölle.

\section{Tulokset}

Haastatteluissa selvisi, että suosituin tekijänoikeuden optimikeston perustelu on utilitarismi. Mielenkiintoisesti sekä tekijänoikeuden nykyistä kestoa että sen lyhentämistä perusteltiin utilitarismilla. Tästä voi päätellä, että tekijänoikeuden keston hyöty- ja haittavaikutukset voi tulkita usealla eri tavalla, ja että perustelujen tueksi on mahdollista löytää keskenään ristiriitaisia tutkimustuloksia. Nykytilanteen kannattajat näkevät, että 70 vuoden kesto antaa erittäin vahvan kannusteen uusien teosten luomiseen. 
Usein väitettiin, että tekijänoikeus mahdollistaa musiikin ammattimaista tekemistä ja siihen sijoitetut taloudelliset panostukset on mahdollista hankkia takaisin. Keston lyhentämisen kannattajat puolestaan näkevät, että nykykesto aiheuttaa uusiokäytön hidastumista ja sisältöjen muumioitumista, joka on kokonaisuutena haitallisempaa kuin pitkästä kestosta koituvat hyödyt.

Tässä artikkelissa keskityn kuitenkin toiseen suosittuun perusteluun eli edellä mainittuun luonnolliseen omistusoikeuteen, joka teoksiin saadaan työtä tekemällä. Haastatteluissa erityisen usein mainittiin omistusoikeuden kautta avautuva mahdollisuus tekijänoikeuksien jättämiseen perintönä tekijän jälkipolville. Tämä oli ylivoimaisesti suosituin yksittäinen tekijänoikeuksien keston perustelun tapa koko aineistossa, nimenomaan nykyisen keston eli 70 vuoden voimassa pitämisen puoltamiseksi. Esimerkiksi Teoston Kim Kuusen mukaan tekijälle tekijänoikeus on "tehtyä työtä, johon hänellä on omistusoikeus”:

Se on elämäntyö, jota tehdään usein ihan niinku määrätietosesti myös ihan niinku kartottamaan varallisuutta ja tota, jota voidaan jättää perillisille ja muuta. Ihan samalla tavalla ku muutakin työtä.

Manageri Aki Roukala puolestaan rinnastaa tekijänoikeuden "ihan täysin" kiinteään omaisuuteen kuten taloon:

Onhan se perintöä ihan samalla tavalla ku mikä tahansa muukin perintö. Että jos aattelee että sä jättäsit talon perinnöksi lapselles, niin sit tultaskin näin et nyt sää oot riittävän kauan asunu tässä, et nyt tää onkin, nyt tänne saakin muuttaa kuka tahansa.

Roukalan mielestä tekijänoikeuden tulisi jatkua "parin kolmen" sukupolven ajan. Toisaalta hänen mukaansa "kun mennään sukupolvesta toiseen, se voi ehkä mennä vähän tarpeettomaksi.” Tämä perustelu eli tekijänoikeuden keston näkeminen perintönä nousi haastatteluissa esiin toistuvasti. Esimerkiksi Suomen Säveltäjien Antti Auvinen näkee tekijän puolison ja lapset integraalisena osana "luovan teoksen tekemisen prosessia" ja katsoo siksi, että heillä on oikeus osallistua tulonjakoon. Auvinen pitää 70 vuoden kestoa eräänlaisena jälkipolvien turvana. Myös musiikintekijä Olavi Uusivirta pitää kahden tekijän jälkeisen sukupolven kattavaa kestoa kohtuullisena ja ajattelee, että taiteilijan koko elämäntyö on juuri tekijänoikeuksia. Uusivirta rinnastaa tekijänoikeuksien perimisen innovaatioita tuottavan yrityksen perimiseen. Samalla tavoin musiikin- 
tekijä Kimmo Pohjonen pitää teostensa tekijänoikeuksia "isona pankkina”, johon on keräytynyt tehtyä työtä.

Useat haastateltavat, kuten MES:n Hannu Saha, pohtivat haastatteluissa yksityishenkilöinä, kuinka kauan kuolleen artistin suvun tulee vielä elää tekijänoikeuksien avulla. Myös Suomen Musiikintekijöiden Aku Toivonen eritteli ja analysoi yksityishenkilönä lyhyemmän tekijänoikeuden keston eri puolia, vaikka hänen edustamansa yhdistyksen virallinen kanta optimiksi onkin nykyinen 70 vuotta tekijän kuolinvuodesta. Finnish Music Startupsien Jiri Koivuniemi puolestaan näkee, että lastenlasten jälkeiset sukupolvet ovat "aika kaukana siitä lähteestä", johon tekijänoikeustulot perustuvat. EFFI ry:n Timo Karjalaisen mukaan ei ole iso ongelma, että esimerkiksi Mozartin suku ei enää tienaa esi-isänsä teoksilla. Keikkajärjestäjä Ilpo Sulkala puolestaan pitää 70 vuotta "kovin pitkänä aikana" ja olisi valmis maksamaan yhdelle tekijän jälkeiselle sukupolvelle, mutta ei pidempään.

Perimistä ja siihen liittyvän lainsäädännön ja perintökaaren (1965) yleistä mielekkyyttä pohti haastatteluissa vain kaksi vastaajaa, musiikintekijät Pasi Siitonen ja Markus Nordenstreng. Siitonen ei ollut varma, onko perimisessä ylipäätään järkeä, mutta huomautti tämän olevan laajempi kysymys, johon haastattelutilanteessa ei ollut mahdollista syventyä. Nordenstrengin mukaan "fundamentaaliset kysymykset", kuten se, onko mikään perintö oikein, voidaan nostaa tekijänoikeuskeskustelussa esiin. Nordenstreng mainitsee esimerkkinä tällaisen keskustelun aloittajasta Stingin, joka ei aio jättää lapsilleen tekijänoikeuksiaan perintönä lainkaan.

Yhteenvetona voi työntekoon perustuvan luonnolliseen omistusoikeuteen kytkeytyvien perustelujen osalta sanoa, että nykyistä kestoa perusteltiin haastatteluissa usein rinnastamalla henkinen omaisuus aineelliseen omaisuuteen. Perinnön jättämisen mahdollisuus oli ylivoimaisesti suosituin tapa perustella nykyistä kestoa tässä luokassa. Tekijänoikeus omistusoikeutena nähtiin yleensä itsestään selvänä. Rajoittamatonta oikeuksien kestoa - kuten fyysisten esineiden kohdalla on, mielenkiintoisesti, tapana ajatella - ei kuitenkaan yleisesti kannatettu, vaan tekijän jälkeiset sukupolvet nähtiin usein sopivana aikana. Haastatteluissa ei myöskään mainittu suoraan syitä, miksi keston tulisi ylipäätään loppua muutaman sukupolven jälkeen. Muutama haastateltu kannatti kolmen sukupolven, mutta yleisesti kahden sukupolven kattava kesto nähtiin hyvänä ratkaisuna. Näin nähtiin oikeutettuna, että tekijän lapsenlapset nauttivat isovanhempansa luomista teoksista taloudellisesti. 


\section{Pohdinta}

Tekijänoikeuden nykyisen keston suhde tekijän jälkeisen kahden ja kolmen sukupolven keskimääräiseen elinikään on hyvin helppo kuvata yksinkertaisen taulukon avulla. Taulukko kuvaa, kuinka kauan tekijän jälkeiset sukupolvet saavat perimistään tekijänoikeustuloista nauttia.

Syntyvyys Suomessa laski vuonna 2018 kahdeksantena vuonna peräkkäin ja se on tällä hetkellä kaikkien aikojen matalin, 1,41 lasta naista kohden. Syntyvyys on laskenut huomattavasti väitöskirjassani tarkastellusta vuodesta 2017 $(1,49)$. Naiset saavat esikoisen keskimäärin 29,4 vuoden iässä, jolloin miehet ovat keskimäärin 31,4 vuoden ikäisiä (keskiarvo 30,4 vuotta). Elinajanodote vuonna 2017 oli miehillä 78,70 ja naisilla 84,20 vuotta (keskiarvo 81,45 vuotta).

Näiden tietojen avulla voidaan esittää seuraava hypoteettinen, keskiarvoihin perustuva tilanne. Siinä 30-vuotiaalle tekijälle syntyy yksi ainoa lapsi. Oletetaan, että myös tälle tekijän lapselle syntyy ainoastaan yksi lapsi (eli tekijän lapsenlapsi), jolloin hän täyttää 30 vuotta. Oletetaan, että nämä luvut pysyvät yli sukupolvien vakioina. Tuloksena saadaan aikaan seuraavat tiedot:

Tekijän kuollessa 80-vuotiaana tekijän lapsi on keskimäärin 50-vuotias. Koska tekijänoikeudet kestävät 70 vuotta tekijän kuolinvuoden jälkeen, tekijän lapsi ehtii nauttia niistä elämänsä loppuun saakka eli jäljellä olevat 30 vuotta. Hänellä itsellään on yksi lapsi eli tekijän lapsenlapi, joka on isovanhempansa kuolinvuotena 20-vuotias ja oman vanhempansa eli tekijän lapsen kuollessa 50-vuotias. Koska tällöin tekijänoikeuksia on jäljellä vielä 40 vuotta ja koska lapsenlapsi elää keskimäärin vielä 30 vuotta, myös hän nauttii perittyjä tekijänoikeuksia elämänsä loppuun saakka. Suoja-aikaa on kuitenkin jäljellä keskimäärin 10 vuotta tekijän lapsenlapsen kuoleman jälkeen, joten tarkasteluun on hyödyllistä lisätä vielä yksi sukupolvi, tekijän lapsenlapsenlapsi. Edellisten sukupolvien tapaan hän perii oikeudet itselleen 50-vuotiaana ja ehtii nauttia niistä 10 vuotta, jolloin suoja-aika lopulta lakkaa. Tällöin tekijän lapsenlapsenlapsi on 60-vuotias. On huomionarvoista, että hän ei ole koskaan tavannut iso-isovanhempaansa eli teoksen tekijää. 
Taulukkona tiedot voi esittää seuraavasti:

Taulukko 2. Tekijänoikeuden kesto perintönä.

\begin{tabular}{lllll}
\hline $\begin{array}{l}\text { Tekijänoikeuden kesto } \\
\text { perintönä }\end{array}$ & $\begin{array}{l}\text { 1. perijäsuku- } \\
\text { polvi (vuotta) }\end{array}$ & $\begin{array}{l}\text { 2. perijäsuku- } \\
\text { polvi (vuotta) }\end{array}$ & $\begin{array}{l}\text { 3.perijäsuku- } \\
\text { polvi (vuotta) }\end{array}$ & $\begin{array}{l}\text { Tekijänoikeutta } \\
\text { jäljellä (vuotta) }\end{array}$ \\
\hline Tekijän kuolinvuosi & 50 & 20 & ei syntynyt & 70 \\
1. perijän kuolinvuosi & kuollut & 50 & 20 & 40 \\
2. perijän kuolinvuosi & kuollut & kuollut & 50 & 10 \\
Tekijänoikeus päättyy & kuollut & kuollut & 60 & 0 \\
\hline
\end{tabular}

Kuten taulukko osoittaa, tekijänoikeuden kesto on tällä hetkellä pidempi kuin tekijän lapsenlapsen elinajanodote. Tästä seuraa, että mikäli tekijänoikeuden nykyistä kestoa perustelee kahden tekijän jälkeisen sukupolven kattavana oikeutena, oikeuden tulisi olla nykyistä lyhyempi. Jos ajatellaan, että lapsenlapsen tulisi nauttia oikeuksista koko elämänsä ajan, keston tulisi olla 60 vuotta tekijän kuoleman jälkeen. Jos puolestaan pidetään kohtuullisena, että ensimmäinen perijäsukupolvi saa nauttia oikeuksista elämänsä loppuun saakka, kesto voitaisiin rajata 30 vuoteen tekijän kuolemasta. Tekijän lapsenlapsi jäisi tällöin vaille tekijänoikeustuloja. Hän on tekijän kuollessa keskimäärin 50-vuotias.

On myös mahdollista ajatella, että tekijänoikeuden tehtävänä on toimia turvana tekijän lapsille esimerkiksi tekijän ennenaikaisen kuoleman tapauksessa. Tällöin tekijänoikeuden kesto voisi olla 18 vuotta tekijän kuoleman jälkeen, jolloin tekijän lapsi tulee viimeistään täysi-ikäiseksi. Suojaaika voisi päättyä myös silloin, kun perijät siirtyvät itse työelämään. Tämän ajankohdan määrittäminen on (ollut) tilastollisesti hankalaa työelämän murroksen lisäksi eri roolien, kuten työn ja opiskelun, yhdistämisen vuoksi (ks. esim. Myrskylä 2014 ja Katainen, Lintunen \& Neuvonen 2019). Vaihtoehtoja on lukuisia. Toisaalta, kahden sukupolven perimistä voidaan myös lähestyä pisimmän mahdollisen takuusuoja-ajan eikä keskiarvojen kautta, eräänlaisena worst case scenariona. Tällöin voidaan ajatella tilanne, jossa miespuolinen tekijä saa lapsen 80-vuotiaana ja kuolee heti. Sama tilanne toistuu tekijän lapsenlapsen syntymän kohdalla. Tällöin tekijänoikeuden keston tulisi olla kahden sukupolven perinnön kattavalla perustelulla 160 vuotta tekijän kuolemasta. Nämä toimikoon esimerkkinä siitä, minkälaisia vaihtoehtoja tekijänoikeuden kestolle on mahdollista laskien esittää tekijän jälkeisten kahden sukupolven kattavan perinnön osalta.

Perintöä ja perimistä koskeva yhteiskunnallinen analyysi on laajempi ja monimutkaisempi asia kuin tässä peruskoulun matematiikan avulla 
suoritettu laskutoimitus. Lisäksi on hyvä muistaa, että sen todistaminen, lisääkö mahdollisuus jättää tekijänoikeudet perintönä teosten kokonaismäärää yhteiskunnassa vai ei, on mahdoton tehtävä. Se vaatisi samaan aikaan tietoja ja dataa tilanteesta, jossa tätä mahdollisuutta ei olisi, ja tilanteesta, jossa tämä mahdollisuus on.

Lopputulemana voidaan esittää, että mikäli tekijänoikeutta perustellaan perintönä niin, että tekijän jälkeiset kaksi sukupolvea voi nauttia tekijänoikeuksista, nykyinen tekijänoikeuden tekijänoikeuden kesto on liian pitkä. Toisin sanoen nykyisen keston perustelu tekijän jälkeisen kahden sukupolven mittaisena perinnön jättämisen mahdollisuutena ei ole validi. Johtopäätöksenä voidaan todeta, että mikäli perintö työnteon ja luonnollisen omistusoikeuden alalajina hyväksytään tärkeimmäksi tekijänoikeuden perusteluksi siten, että tekijän jälkeiset kaksi sukupolvea voivat nauttia tekijänoikeuksista, nykyinen tekijänoikeuden kesto tulisi lyhentää 60 vuoteen tekijän kuolinvuodesta. Vaihtoehtoisesti tämä perustelun tapa voidaan nykytilanteessa hylätä.

Miten tämä kaikki liittyy tällä hetkellä esivalmistelussa olevaan, tekijänoikeusdirektiiviin perustuvaan uuteen tekijänoikeuslakiin, joka tulee voimaan viimeistään kesäkuussa 2021? Kuten artikkelin alussa totesin, tulevan vajaan kahden vuoden aikana käytävän, uuteen tekijänoikeusdirektiiviin liittyvän tekijänoikeuskeskustelun kannalta on yksinkertaisesti hyödyllistä tietää, mikä voimassa olevan tekijänoikeuden kesto on ja miten sitä perustellaan erityisesti musiikkialalla, jolle alustapalvelujen toimintalogiikan muutos on luovista aloista merkittävin. Kuten Teoston (2019) nettisivuilla kerrotaan, "verkossa toimivien alustapalveluiden tulee hankkia asianmukaiset tekijänoikeusluvat tarjotessaan yleisölle kuluttajien lataamia sisältöjä. Alustapalveluiden pitää maksaa sisältöjen alkuperäisille tekijöille (oikeudenhaltijoille) asianmukaiset tekijänoikeuskorvaukset ja huolehtia yhteistyössä myös sisältöjen tekijöiden kanssa luvattomien sisältöjen poistamisesta”. On huomionarvoista, että suuri osa näistä korvauksista tuloutuu tekijöiden sijaan oikeuksien perijöille. Heistä osa ei ole teoksen tekijää koskaan edes tavannut.

\section{Lähteet}

Eskola, Jari \& Vastamäki, Jussi (2010). Teemahaastattelu: opit ja opetukset. Teoksessa Aaltoja, Juhani \& Valli, Raine (toim.), Ikkunoita tutkimusmetodeihin 1. Metodin valinta ja aineistonkeruu: virikkeitä aloittelevalle tutkijalle, 26-32. Jyväskylä: PS-Kustannus.

Euroopan parlamentin ja neuvoston direktiivi (EU) 2019/709. 
Euroopan parlamentin ja neuvoston direktiivi (EU) 2011/77.

Euroopan parlamentin ja neuvoston direktiivi (EY) 2006/116.

Euroopan parlamentti (2019). Euroopan parlamentti hyväksyi uudet digitaaliset tekijänoikeussäännöt. Lehdistötiedote, 26.3.2019. http://www. europarl. europa.eu/news/fi/press room/20190321IPR32110/euroopan-parlamentti-hyvaksyi-uudet-digitaaliset-tekijanoikeussaannot.

Haarmann, Pirkko-Liisa (2014). Immateriaalioikeus (5. uud. p.). Helsinki: Talentum.

Halminen, Laura (2019). Kuka saa jakaa musiikkia, miten käy meemeille? Tätä kaikkea uudet digi-tekijänoikeudet tarkoittavat. Helsingin Sanomat, 27.3.2019. https://www.hs.fi/teknologia/art-2000006049981.html.

Katainen, Antti, Lintunen, Jenni \& Neuvonen, Samuli (2019). Nykyiset kolmekymppiset opiskelevat - edellinen sukupolvi oli 30-vuotiaana työelämässä. Tieto \& Trendit. https ://www. stat.fi/ tietotrendit/artikkelit/2019/nykyiset-kolmekymppiset-opiskelevat-edellinen-sukupolvi-oli-30-vuotiaana-tyoelamassa/.

Leppämäki, Laura (2007). Tekijänoikeudeton alue: public domain. Teoksessa Mylly, Tuomas, Lavapuro, Juho \& Karo, Marko (toim.), Tekemisen vapaus. Luovuuden ehdot ja tekijänoikeus. Helsinki: Gaudeamus.

Leppämäki, Laura (2006). Tekijänoikeuden oikeuttaminen. Jyväskylä Studies in Education, Psychology and Social Research 284. Jyväskylä: Jyväskylä University Printing House.

Myrskylä, Pekka (2014). Milloin työura alkaa ja loppuu? Tieto \& Trendit. https://www.stat.fi/ tietotrendit/artikkelit/2014/milloin-tyoura-alkaa-ja-loppuu/.

Nordgård, Daniel (2018). Henkilökohtainen tiedonanto 14.12.2018. Music, Digitalisation and Democracy Study Day. Åbo Akademi, Turku.

Perintökaari 1965/40. Annettu Helsingissä 5.2.1965. https://www. finlex.fi/fi/laki/ajantasa/1965/19650040\#V5.

Raivio, Petri (2019). Euroopan parlamentti hyväksyi lopullisesti uuden tekijänoikeuslain - Tekijöille lisää oikeuksia, ilmaiset uutislinkit uhan alle. Yleisradio, 26.3.2019. https://yle.fi/ uutiset/3-10707635.

Rytinki, Markus (2018). Musiikkialan tekijänoikeuksien kesto, ansaintalogiikat ja digitaalisen aineiston saatavuus internetissä. Acta Universitatis Ouluensis B 169. Oulu: Oulun yliopisto. Väitöskirja. http://urn.fi/urn:isbn: 9789526221182

Tekijänoikeuslaki 1961/404. Annettu Helsingissä 8.7.1961. https://www.finlex.fi/fi/laki/ajantasa/1961/19610404\#L5.

Teosto (2019). EU:n tekijänoikeusdirektiivi hyväksytty: parannus sisällöntekijöiden neuvotteluasemaan. https://www.teosto.fi/teosto/uutiset/eu-tekijanoikeusdirektiivi-hyvaksytty.

Teosto (2019). EU:n tekijänoikeusuudistus ja artikla 13 - mistä on kyse? https://www. teosto.fi/ teosto/uutiset/eu-tekijanoikeusuudistus-mista-kyse.

Tilastokeskus (2018). Elinajanodote. Päivitetty 26.10.2018. https://findikaattori.fi/fi/table/46. Tuomi, Jouni \& Sarajärvi, Anneli (2002). Laadullinen tutkimus ja sisällönanalyysi. Helsinki: Tammi.

Tuomi, Jouni \& Sarajärvi, Anneli (2013). Laadullinen tutkimus ja sisällönanalyysi. Helsinki: Tammi. 


\section{Tutkimuksen informantit}

Auvinen, Antti, puheenjohtaja, Suomen Säveltäjät ry

Apajalahti, Ahto, Helsingin piiriyhdistyksen puheenjohtaja, Piraattipuolue ry

Berglund, Joose, omistaja, Stupido Records

Ehnrooth, Jacob, omistaja, Bassoradio

Elbanna, Samy, musiikintekijä, muusikko

Elivuo, Rafael, A\&R manager, Kaiku Songs

Hietanen, Herkko, lakimies, perustajaosakas, Turre Legal

Jarva, Marisanna, kansanedustaja (kesk.), sivistysvaliokunnan jäsen

Karjalainen, Timo, puheenjohtaja, Electronic Frontier Finland ry

Kivelä, Kimmo, kansanedustaja (ps), sivistysvaliokunnan jäsen

Kivitie, Essi, CEO, partner, Rähinä Records

Koivuniemi, Jiri, toiminnanjohtaja, Visionist Oy

Kosonen, Antti, tuottaja, PME Records

Kotilainen, Antti, toiminnanjohtaja, IFPI Finland

Kuusi, Kim, hallituksen puheenjohtaja, Teosto

Kyyrä, Tommi, apulaisjohtaja, IFPI Finland

Lipponen, Jyri, omistaja, Levykauppa Äx

Mylly, Tuomas, professori, Turun yliopisto

Mäkinen, Rene, ohjelmajohtaja, Bauer Media Oy

Nordenstreng, Markus, musiikintekijä, muusikko

Oskala, Hannu, asiantuntija, Helsingin kaupunginvaltuutettu (vihr.)

Pannula, Tom, General Manager Finland, Playground Music Finland

Pihlajarinne, Taina, professori, Helsingin yliopisto

Pitkänen, Olli, toiminnanjohtaja, professori, IPR University Center

Pohjonen, Kimmo, musiikintekijä, muusikko

Poroila, Heikki, kirjastonhoitaja, Vantaan kaupunginkirjasto (eläkkeellä)

Raito, Mikko, lakimies, Elisa oyj

Rislakki, Juha, lakimies, Tekijänoikeuden tiedotus- ja valvontakeskus ry

Roukala, Aki, agentti, Is This Art?

Saha, Hannu, johtaja, Musiikin edistämissäätiö MES

Siitonen, Pasi, musiikintekijä, muusikko

Sipilä, Pekka, toiminnanjohtaja, Suomen Musiikkikustantajat ry

Sorsa, Katariina, Export Manager, pop and rock, Music Finland ry

Sulkala, Ilpo, keikkajärjestäjä, ravintola/yökerho 45 Special, Oulu

Sutela, Juha, palvelupäällikkö, musiikkikirjastopalvelut, Oulun kaupunginkirjasto

Toivola, Jani, kansanedustaja (vihr.), sivistysvaliokunnan jäsen

Toivonen, Aku, toiminnanjohtaja, Suomen Musiikintekijät ry

Uusivirta, Olavi, musiikintekijä, muusikko

Valtanen, Kimmo, toimitusjohtaja, Universal Music Finland

Vänttinen, Ahti, puheenjohtaja, Suomen Muusikkojen Liitto ry 